APPLICATION OF ERP SYSTEM MODULE AS A MINE FOREMAN ASSISTANCE

A. Burduk ${ }^{1}$, T. Chlebus ${ }^{1}$, P. Stefaniak ${ }^{2} *$

${ }^{1}$ Wroctaw University of Technology

27 Wybrzeże Wyspiańskiego

50-370 Wroctaw, Poland

${ }^{2}$ KGHM Cuprum Sp. zo.o. Research and Development Centre

2-8 Sikorskiego Street

53-659 Wroctaw, Poland

("Corresponding author: pstefaniak@cuprum.wroc.pl) 


\begin{abstract}
The traditional approach to managing information flow between a mine underground and overground, applied in copper mines of KGHM Polska Miedź S.A., is mostly based on exchanging spoken information using the mine telephone network and printed documentation. This way of information flow significantly influences effective use of time of a shift foreman employed at a mining division. In order to minimise multiplication of significant information generated as paper documentation, a concept of an IT system module to input basic data concerning operation of the mining division was developed. The idea is based on computer software that permits inputting data in the underground and their immediate sending to the overground. The above-mentioned solution will permit significant reduction of administrative work time that each foreman has to do on each shift. The time saved on filling forms and communication will permit the foreman and the other workers involved in information flow to spend more time for execution of their basic duties. In the case of the supervision employees working in the overground, the IT system will allow all the interested persons to be informed directly, with no necessity to transfer the information on the situation in the given mining division by turns from one to another. On the other hand, saving time on administrative works will permit the foreman employed in the underground executing more detailed inspection of workplaces in his subordinate mine division. Thus, availability of the foreman for the mining division operation will be improved.
\end{abstract}

\title{
KEYWORDS
}

information flow, ERP system, electronic data exchange

\section{PRESENT INFORMATION FLOW SYSTEM}

The first step towards developing a concept of an IT module for inputting basic data on the mining division operation was analysing the present condition. This condition was analysed on the grounds of observations made in a mine, in one of its mining divisions. Currently, a mine foreman working in underground records all the data on the division operation in paper form and next, as necessary, transmits them by telephone to chief foremen and other interested persons in the overground. Then, after making notes, the overground employees enter a part of the data obtained by telephone to electronic datasheets. Moreover, after each shift, the selected documents brought by the shift foreman from the mining division are also recorded in electronic form. The so prepared information is transferred to the involved departments of the mine administration. At present, a foreman records ca. a hundred data in variable forms. Due to requirements of the of the mining law, some of these data are present in several documents. 


\section{ERP SYSTEM MODULE}

The ERP (Enterprise Resource Planning) class system is a system for a company management that includes all functions and components of manufacturing, accounting and HR (Human Resources) systems. The software is to integrate all functions of the company. The suggested one is the ProEdims designed by Polish programmers from Lower Silesian Innovation and Science Park and Wroclaw University of Technology. It belongs to the family of products that manage processes in the company and the product data. It permits creating, accumulating, managing and distributing all the information and data necessary for efficient operation of the company, as well as the data related to the product during its whole life cycle. It ensures also transparent maps of information flow, documentation, decision and work in the company complete knowledge about business processes in the on-line mode. It is a multifunction system for managing resources and projects. Modular structure of such a software makes it open, so it can be extended by additional functions depending on customers' needs. In the case of a mine, the module to extend the ERP system is the system component designed for acquiring data by the mining division foreman. This module should significantly simplify and reduce the time for inputting information to the mine IT system, since the data loaded to the system would be transferred directly to the mine database and made accessible for other involved workplaces. Since the system works in real mode, there is no need to process data once again, like it is in the present data management system. Implementing such an ERP module will permit eliminating ca. $25 \%$ of repeated information, which is measurably converted to the time assigned for work in the mining area. Another advantage of implementing this system is elimination of errors during generation of documents, since they would be created automatically on the grounds of standard forms.

A schematic diagram of the module managing electronic data exchange is shown in Figure 1. The element of process which initialize process flow and processing of information in related to the work of miners is to get equipment from the lamp room. This fact is collected in ERP module and begin process of work registration. In this way, the system receives information on the number of worker going down to the mine, which is directly converted to the employee in a mining closet. After the work team reaches its mining closet, the shift foreman verifies the manpower of the newly arrived staff, as well as assigns tasks and resources to individual workers. The next step would be entering to the system (and not to paper forms) the data related to the progress of mining works and those related to managing machinery. This information is currently saved in the ProEdims database. The information received from the lamp room would be used for generating documents based on forms in automated way. The documents would be stored in electronic form and those required by the mining law would be printed and archived. The same

database would be also used by administrative departments responsible for accounting the work of mining work teams eg. MOPRONA - Ore production monitoring system. 


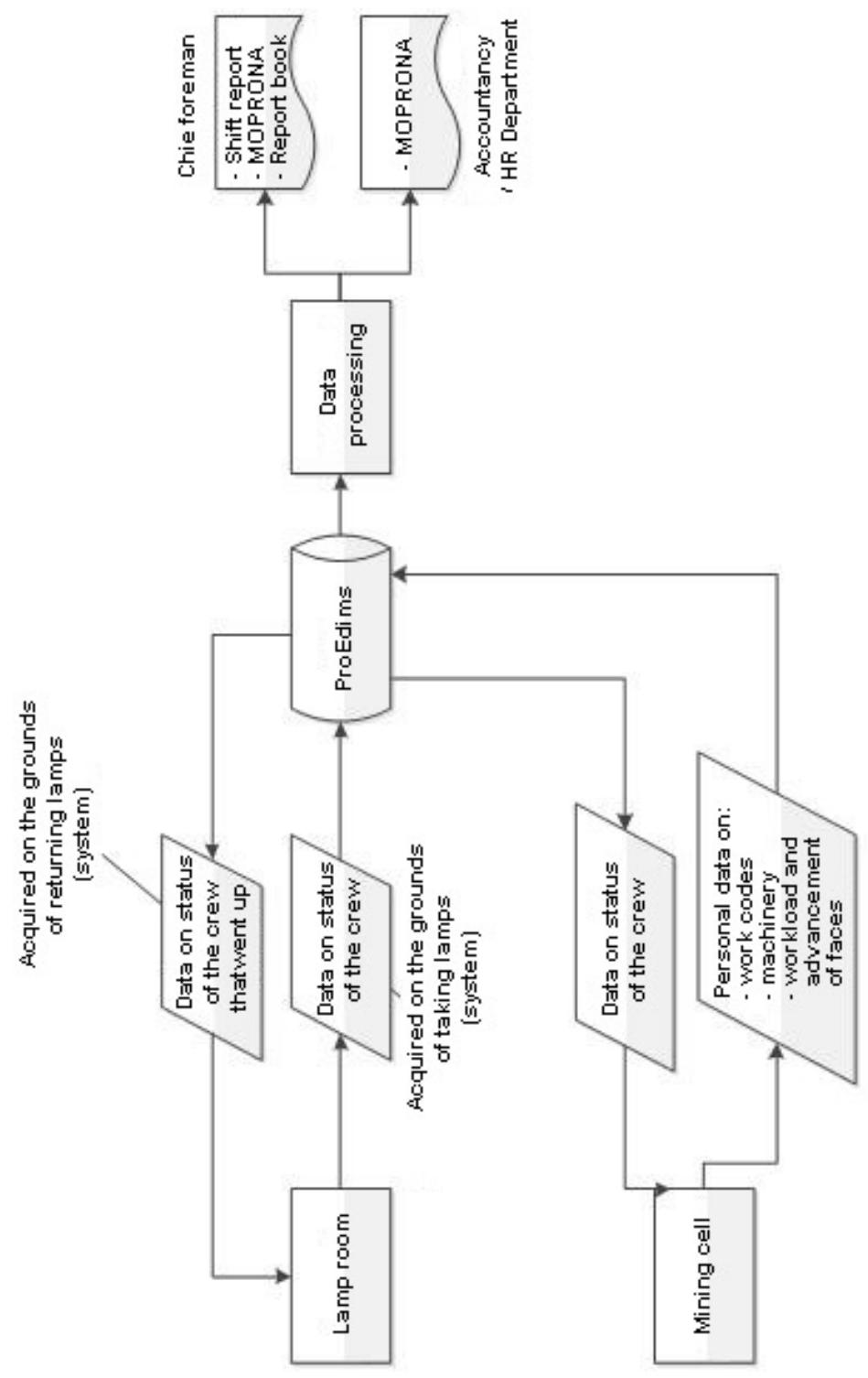

Figure 1 - Schematic diagram of the module managing electronic data exchange

\section{ANALYSIS}

All the observations were made at the same mining division during the first and the second shift. Observed was the work of four foremen. Table 1 shows averaged times of individual groups of activities performed by a mining shift foreman. The most important activity in a foreman's work is his work in the mining area and, as presumed, the foreman should spend most time just on it. 
It results from Figure 2 that administrative processes absorb most of the time and make ca. $50 \%$ of the whole foreman's work time. A large part of administrative activities is composed of contacting with other employees of the mine and filling forms.

Table 1 - Main activities of a mine foreman and time of their performing[2]

\begin{tabular}{|l|c|}
\hline Activities of a mine foreman & Duration [min] \\
\hline Briefing at the overground & 20 \\
\hline Transport to the workplace & 40 \\
\hline Administrative works in the mining cell & 80 \\
\hline Work in the mining area & 140 \\
\hline Administrative works in the mining cell & 140 \\
\hline Transport from the workplace & 40 \\
\hline Administrative works in the division foreman's house & 20 \\
\hline Total worktime & 480 \\
\hline
\end{tabular}

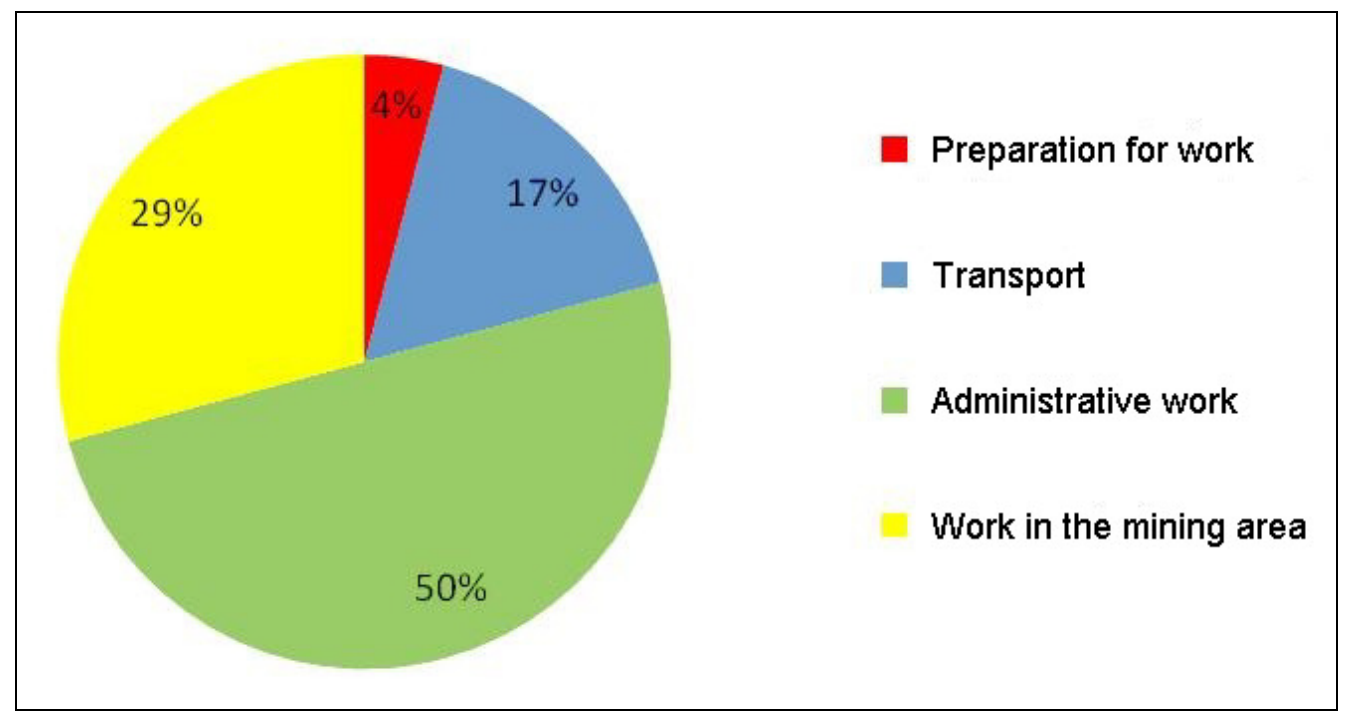

Figure 2 - Total work time of a shift foreman working at the mining division

At the same time, transferred is also verbal information to the superiors at the overground, using a telephone. The overground workers record also some data in paper form, so that a subsequent person enters them later to a computer data sheet. Complete documentation of the mining division filled by the foreman consists of 11 documents, as listed in Table 2. A significant part of these documents could be filled in electronic form. Many times, the employees make use of graphic codes conventionally assigned to some activities or events. It would be also possible in electronic form, e.g. by choosing a suitable graphic symbol from a previously created database. 
Table 2 - List of documents filled by a mine shift foreman

\begin{tabular}{|c|l|l|}
\hline Item & Document name & Filling \\
\hline 1. & Shift report & During shift \\
\hline 2. & Report book & During shift \\
\hline 3. & Production monitoring MOPRONA & During shift \\
\hline 4. & $\begin{array}{l}\text { Shift control book of the crew going up } \\
\text { and down }\end{array}$ & After going up \\
\hline 5. & Liquidation worksheet & After going up \\
\hline 6. & Book of weekly industrial safety training & Once a week \\
\hline 7. & $\begin{array}{l}\text { Book of monthly industrial safety training } \\
\text { of mining machines operators }\end{array}$ & Once a month \\
\hline 8. & Book of rock management & After going up \\
\hline 9. & Face venting book & $\begin{array}{l}\text { After going up, } \\
\text { once a day }\end{array}$ \\
\hline 10. & Radio-telephone receipt and issuance book & Before going down \\
\hline 11. & Foreman's personal notes & During shift \\
\hline
\end{tabular}

\section{SUMMARY}

As can be deduced from the above analysis, the foreman spends $29 \%$ of his work time for the most important activity during a shift. It is possible to extend this time by introducing an IT module for inputting basic data concerning operation of the mining division. The module not only permits the division foreman to pay more attention to what happens directly in the mining area, but reduces also the number of paper documents that include often the same information. In addition, the module will permit faster transferring the data that at present are mainly communicated by telephone and in paper form. Sometimes, this requires from the shift foreman to transfer the same information to other mine employees repeatedly. Thanks to the module, the data entered to a computer in the division mining cell would be available on-line - via the shift foreman - for the persons needing an insight into specific information. With respect to mining requirements and regulations, some information must be archived in paper form, as determined by the regulations. To satisfy this requirement, the module will automatically assign the input data to electronic forms prepared according to a pattern. The so prepared forms will be next printed, duly stamped, signed and archived.

\section{REFERENCES}

Elaboration of KGHM CUPRUM Sp. z o.o., Research and Development Centre, Mining, Wrocław, Poland (in Polish)

\section{Source materials gained from the Mine}

Burduk A., Chlebus T., Helman J., Rosienkiewicz M., Teodorski D.: Analysis of a possibility to apply computer assistance of shift foreman work at a mining division. Systems. Journal of transdisciplinary systems science, 16, issue 2, Wrocław 2012, p. 67 (in Polish) 